\title{
Foraging Patterns of Cavity-Nesting Birds in Fire-Suppressed and Prescribe-burned Ponderosa Pine Forests in Montana
}

\author{
Jennifer C. Pierson ${ }^{* 1, \#}$, L. Scott Mills ${ }^{1}$ and Donald P. Christian ${ }^{2, \S}$ \\ ${ }^{I}$ Wildlife Biology Program, The University of Montana, Missoula, Montana 59812, USA \\ ${ }^{2}$ Division of Biological Sciences and Wildlife Biology Program, The University of Montana, Missoula, Montana 59812, \\ USA
}

\begin{abstract}
Fuel-reduction/forest restoration treatments that consist of thinning followed by prescribed burning are becoming increasingly important land management actions that likely affect various wildlife species. To assess potential effects on bark-gleaning birds, we compared the foraging patterns of five cavity-nesting species in thinned and burned ponderosa pine (Pinus ponderosa) forest sites and control sites. We recorded foraging behavior, location on forage tree, and tree characteristics that may be important in the selection of foraging substrates. Foraging surveys were conducted on three replicate 20-ha thinned/burned plots located within larger treatments that ranged from 60 - 250 ha, paired with three replicate control plots. Red-breasted Nuthatches (Sitta canadensis) foraged more often in control sites. Mountain Chickadees (Poecile gambeli) foraged at similar rates on both treatment types. Black-backed Woodpeckers (Picoides arcticus), Hairy Woodpeckers (P. villosus) and White-breasted Nuthatches (Sitta carolinensis) foraged almost exclusively in thinned/burned sites. Overall, all species selectively foraged on larger diameter trees. In control sites, Red-breasted Nuthatches selected larger ponderosa pine trees and Mountain Chickadees selected larger, live trees. In thinned/burned sites, Red-breasted Nuthatches selected larger, live trees, Mountain Chickadees selected larger trees with more canopy connections, Black-backed Woodpeckers selected trees with beetle evidence present and Hairy Woodpeckers selected recently dead trees. These results suggest fuel reduction/forest restoration treatments in dry ponderosa pine forests may be compatible with providing foraging substrates for cavity-nesting species often present in post-fire habitats.
\end{abstract}

Keywords: Cavity-nesting bird, chickadee, foraging, fuel-reduction, prescribed fire, nuthatch, woodpecker.

\section{INTRODUCTION}

Historically, low-elevation ponderosa pine (Pinus ponderosa) forests were typically maintained in an open, uneven-aged state by fire, insect depredations and agerelated mortality $[1,2]$. Fire suppression in ponderosa pine forests has resulted in a change in species composition [3], such as an increase in the shade-tolerant Douglas-fir (Pseudotsuga menziesii), and a denser understory [4]. This transition has produced higher fuel loads, reduced soil moisture and nutrient availability, increased fire severity and size $[4,5,6]$ and increased scale of insect outbreaks such as Douglas-fir tussock moth (Orgyia pseudotsugata McDunnough) [7]. These major changes in landscape patterns affect many wildlife species [7], namely by increasing habitat for closed canopy forest species and decreasing habitat for those that traditionally rely on standreplacement burns, such as woodpeckers $[8,9]$. A recent review of fire and avian ecology [10] pointed out that

*Address correspondence to this author at the CSIRO Plant Industry, Black Mountain Site, PO Box 1600, Canberra, ACT, 2601, Australia; Tel: +61 02 6246 4890; Fax: +61 026246 5166;

E-mail: jencpierson@gmail.com

\#Current Address: CSIRO Plant Industry, Black Mountain Site, PO Box 1600, Canberra, ACT, 2601, Australia

${ }^{\S}$ Current Address: Academic Affairs, State University of New York-New Paltz, New Paltz, NY 12561, USA prescribed fire may be the best tool for reintroducing fire to North American ecosystems and identified the effects of prescribed fire on woodpecker populations as a pressing research need.

Primary cavity-nesting birds play a vital role as strongly interacting 'forest engineers' in many ecosystems by excavating nest cavities for a diverse array of secondary cavity-nesting species [11, 12], regulating bark beetle densities [13], influencing snag decay rates [14] and dispersing wood-living fungi [15]. Therefore, most agencies have snag retention guidelines that aim to provide the necessary resources for primary cavity-nesters for both traditional silvicultural practices and salvage logging operations $[16,17]$.

However, these guidelines are based on snag requirements for nest sites, not foraging resources $[17,18]$. Many studies have considered the effects of forest management practices and natural fires on nest availability for cavity nesting birds and found a diversity of dead and diseased trees is required to provide nesting habitat for different primary cavity nesters [19-22]. As weak primary cavity nesters, Red-breasted Nuthatches (Sitta canadensis) and Mountain Chickadees (Poecile gambeli) require soft snags to excavate their nests [23]. White-breasted Nuthatches (Sitta carolinensis) rely on natural cavities or old woodpecker cavities for nest sites [24]. Strong primary excavators (woodpeckers) require a range of snags, from small-diameter hard snags excavated by Black-backed 
(Picoides arcticus) and Hairy Woodpeckers (P. villosus) to large-diameter soft snags excavated by Lewis's Woodpecker (Melanerpes lewis) [22].

The availability of high quality foraging sites may actually be more limiting than nest sites, especially in recently burned areas where snags are abundant $[19,25,26]$. Brawn and Balda [27] found that availability of nest sites affected Mountain Chickadee densities only moderately and had no effect on White-breasted Nuthatch densities. Consequently, researchers have begun to focus more on the snag characteristics that provide high quality foraging resources [28-30].

Many primary cavity-nesting birds are also bark-gleaners whose food resources will likely shift as a result of thinning and prescribed fire. Many bark-gleaning birds forage on beetles [31-33] with arboreal arthropods being more commonly eaten by smaller birds [21]. However, many barkgleaners feed on live trees as well [21]. Areas that have been managed by combinations of thinning and prescribed fire [1, 34] represent a particularly pressing habitat type to investigate because of the increasing prevalence of this management approach and the likely diverse effects on species using habitat pre- and post-treatment [10].

Western Montana contains nearly two million ha of pine/fir forests historically maintained by frequent lowintensity fire $[35,36]$. Following nearly a century of fire suppression in western forests, land management agencies (e.g., United States Forest Service) increased the acreage treated with fuel reduction/restoration treatments by nearly 30 percent between 2002 and 2003 [37]. Nationally, the Healthy Forest Restoration Act [38], which calls for the active management of forests by reducing the accumulation of fuels, has generated a major shift in land management practices.

The goal of this study is to compare the prevalence of foraging activities and selection of forage trees by five common cavity-nesting birds in this new and increasingly widespread habitat type being created by thinning and prescribed burning in low elevation pine/fir forests. In particular, our study focused on Black-backed Woodpeckers, Hairy Woodpeckers, Red-breasted Nuthatches, Whitebreasted Nuthatches and Mountain Chickadees. These species provide a range of habitat use by cavity-nesting/barkgleaning species. Black-backed Woodpeckers are nearly restricted to early post-fire habitat $[8,9,17]$. Hairy Woodpeckers are commonly found in burned [39] and unburned areas that include a range of management activities (e.g., salvage-logged and thinned sites) [20, 22, 40, 41]. Both woodpeckers overlap in many habitat characteristics for nestsites, nest trees and foraging behavior/resources [42, 43]. Red-breasted Nuthatches and Mountain Chickadees are commonly associated with forests having high canopy closure [44], whereas White-breasted Nuthatches prefer open woodlands [45].

\section{MATERIALS AND METHODOLOGY}

\section{Study Site and Design}

Study sites were located within the boundaries of The University of Montana's Lubrecht Experimental Forest (11,000 ha), $38 \mathrm{~km} \mathrm{NE}$ of Missoula, MT at approximately
$1200-1350 \mathrm{~m}$ elevation. The area was heavily logged in the early 1900s, with subsequent fire exclusion. The secondgrowth ponderosa pine/Douglas-fir/western larch (Larix occidentalis) forests represent xeric, low-elevation forest conditions common in western Montana.

The study design consisted of three control plots $(\mathrm{C} 1, \mathrm{C} 2$, C3, 14 - 20-ha) paired with three treatment plots that were thinned and burned (TB1, TB2, TB3, 20-ha each). The treatment plots were located on Montana Department of Natural Resources' (DNRC) land located within the boundaries of Lubrecht Experimental Forest. Thinning on the treatment sites occurred in the winter of 1998/1999 and consisted of standard treatments conducted by DNRC for ponderosa pine forests fuel-reduction that had combined goals of fuel reduction and forest restoration [1]. Posttreatment basal area objective was $60 \mathrm{ft}^{2}\left(5.5 \mathrm{~m}^{2}\right)$ with ponderosa pine and western larch selected as leave trees. A prescribed broadcast burn was conducted in the spring of 2000. The size of treatments ranged from 60 ha to 250 ha, with our 20-ha study plots located within treatment boundaries. Each plot had a $75-\mathrm{m}$ buffer from any defined habitat edge (road, habitat-type change).

Fire severity is the effect of the fire on the landscape, as it affects the forest floor, tree canopy and other parts of the ecosystem and can be measured by tree mortality and ground fire severity ratings [46]. We characterized fire severity in all three treatment plots with a systematic sampling scheme based on 29 - 49 grid-points per 20-ha plot. We adapted the methodology recommended by Ryan and Noste [46], using the maximum crown scorch height at each grid-point, as opposed to the average, to be conservative in reporting severity. We estimated ground fire severity using ocular estimates of percent cover of ground char and tree mortality was obtained by counting the number of trees that survived compared to the number of trees killed by the fire within a10-m radius of each gridpoint.

One treatment plot, TB1, was dominated by flame length class 2 (crown scorch up to $7.3 \mathrm{~m}$ ) and class 3 (crown scorch up to $19.5 \mathrm{~m}$ ), and high levels of sapling (dbh: $0.5-12.5 \mathrm{~cm}$ ) and pole tree $(\mathrm{dbh}: 12.5-22.5 \mathrm{~cm})$ mortality. The second treatment plot, TB2, was highly variable for tree mortality with many areas suffering only seedling (dbh: $<0.5 \mathrm{~cm})$ and sapling mortality, while other points incurred pole and medium-sized tree (dbh: $22.5-37.5 \mathrm{~cm})$ mortality. The third treatment plot, TB3, was the least severe in terms of above ground tree mortality, with most points indicating mortality for seedlings and saplings only. Light/moderate ground char dominated all sites.

\section{Foraging Surveys}

We conducted foraging surveys during the breeding season, May - August 2001 and 2002. During a survey, an observer walked a systematic, non-overlapping grid with 50 $\mathrm{m}$ spacing in $1 \mathrm{~h}$ effort increments between 05:30 - 12:00. During both seasons, sampling effort included $385 \mathrm{~h}$ in treatment sites and $233 \mathrm{~h}$ in control sites and was spread evenly across study plots. The difference in effort was due to reduced effort in the control sites in 2002 after management treatments conducted in spring 2002 adjacent to the sites resulted in a size reduction of the control plots to retain buffer size $(14-20$ ha). 
We rotated observers among sites and starting points each morning to ensure equal coverage of the plot during different times of the morning. When a target species was seen or heard within $100 \mathrm{~m}$, it was followed until a foraging bout was observed; we recorded only the initial foraging bout $[47,48]$. Once a foraging bout was observed, the clock was stopped while observers recorded bird behavior (Table 1) and characteristics of the forage tree (Table 2). As foliage color and retention are both indicators of time since tree death, they were always included in candidate models together. The observer then returned to the transect and continued the survey. To increase the independence of samples, foraging bouts of same-sex individual woodpeckers were recorded only if they were $>200 \mathrm{~m}$ apart; foraging bouts of individual chickadees and nuthatches (either sex) were recorded only if they were $>100 \mathrm{~m}$ apart $[47,49]$.

Table 1. Behavioral Information Collected During Each Foraging Observation

\begin{tabular}{|l|l|}
\hline Bird Behavior & \multicolumn{1}{|c|}{ Description } \\
\hline \hline Forage Behavior & GL: glean \\
& PR: probe in crevice \\
& PK: peck \\
& SC: scaling by driving bill into bark at an angle \\
& EX: excavating (leaving > 1 cm hole) \\
\hline tree component & B: bole \\
& LP: proximal end of live branch \\
& LM: middle portion of live branch \\
& LD: distal end of live branch \\
& DP: proximal end of dead branch \\
& DM: middle of dead branch \\
& DD: distal end of live branch \\
& C: cone \\
\hline vertical strata & L: lower third of tree or snag \\
& M: middle third of tree or snag \\
& H: upper third of tree or snag \\
\hline
\end{tabular}

To evaluate selection of trees immediately available to birds, we chose a random tree within $50 \mathrm{~m}$ of the tree upon which the bird was observed foraging. Each foraging tree was paired with a tree at a random direction and distance $(<$ $50 \mathrm{~m}$ ) away and the same tree characteristics were recorded for each random tree as the forage trees (Table 2).

\section{Statistical Analysis}

In order to evaluate the intensity of use of each treatment type, we calculated the average encounter rates by dividing the number of foraging bouts by the total number of hours spent surveying each treatment type. A $\chi^{2}$ test was used to determine if the encounter rates of each species was different between control and thinned/burned sites.

Selection of foraging trees was evaluated separately for each bird species using a logistic regression approach [50]. Although all observations clearly do not represent individual birds, we attempted to increase the independence of samples through constraints on sequential observations of the same bird, as noted above.
Table 2. Description of Tree Characteristics Recorded on Forage Trees and Random Trees

\begin{tabular}{|c|c|c|}
\hline $\begin{array}{c}\text { Tree } \\
\text { Characteristic }\end{array}$ & Description & $\begin{array}{c}\text { Variable } \\
\text { Description }\end{array}$ \\
\hline class & $\begin{array}{l}0: \text { live } \\
1: \text { dead }\end{array}$ & categorical \\
\hline spp & $\begin{array}{l}\text { tree species: ponderosa pine, } \\
\text { Douglas-fir, } \\
\text { other species: western larch, } \\
\text { lodgepole pine }\end{array}$ & categorical \\
\hline dbh & tree diameter at breast height $(\mathrm{cm})$ & continuous \\
\hline bark & $\begin{array}{l}\text { bark retention } \\
0: 0 \% \\
1: 1-49 \% \\
2: 50-99 \% \\
3: 100 \%\end{array}$ & categorical \\
\hline can & $\begin{array}{l}\text { canopy connections; obtained by an } \\
\text { observer standing at the base of the } \\
\text { tree and determines } \\
\text { if there is a canopy connection at } \\
\mathrm{N}, \mathrm{NE}, \mathrm{E}, \mathrm{SE}, \mathrm{S}, \mathrm{SW}, \mathrm{W}, \mathrm{NW} \\
0-8 \text { possible per tree }\end{array}$ & continuous \\
\hline fir & $\begin{array}{l}\text { fire effects } \\
0: \text { no fire effects } \\
\text { 1: bole scorch only } \\
2: \text { crown partially scorched } \\
3: \text { crown entirely scorched }\end{array}$ & categorical \\
\hline btl & $\begin{array}{l}\text { beetle evidence } \\
0: \text { no beetle evidence } \\
\text { 1: beetle entrance or exit holes evident }\end{array}$ & categorical \\
\hline folC & $\begin{array}{l}\text { dominant foliage color } \\
\text { G: green } \\
\text { R: red } \\
\text { NA: no foliage }\end{array}$ & categorical \\
\hline folR & $\begin{array}{l}\text { foliage retention } \\
0: 0 \% \\
1: 1-49 \% \\
2: 50-99 \% \\
3: 100 \%\end{array}$ & categorical \\
\hline
\end{tabular}

We used Akaike's Information Criterion corrected for small sample sizes $\left(\mathrm{AIC}_{c}\right)$, to determine the most parsimonious model from the data [51]. A different candidate model set was developed for each species based on a combination of previous knowledge of foraging patterns in other habitat types and considerations for interpreting models at the management level (i.e., only included interactions that were interpretable at the management level), and included a null model. Candidate model sets were $a$ priori hypotheses regarding what tree characteristics may determine selection of a forage tree based on what is already known about each bird species' foraging behavior and forest characteristics likely to change due to the thinning/burning treatment (Table 2; Appendix 1). All candidate model sets included univariate models considering class, $\mathrm{dbh}$, tree species, fire effects, and canopy connections and all but the 
Mountain Chickadee candidate model set included beetle evidence. We excluded beetle evidence from the Mountain Chickadee model set because they generally forage on the surface of the bark. We considered all bivariate combinations of the variables as well as the interaction between tree class and $\mathrm{dbh}$, and tree class and tree species for all bird species except White-breasted Nuthatches. Due to a small sample size for White-breasted Nuthatches, the candidate model set did not include any interaction terms. We evaluated 34 candidate models for Red-breasted Nuthatches, a species commonly associated with a large variety of habitat types [52]. Additional models considered included the interaction between tree species and dbh, beetle evidence and fire effects, tree class and beetle evidence, and tree species and beetle evidence and several more complex additive models. We evaluated 25 candidate models for Mountain Chickadees, a species commonly associated with montane coniferous forests [53]. Due to a small sample size for White-breasted Nuthatches, we only evaluated 17 candidate models. The candidate model sets for Black-backed Woodpeckers $(\mathrm{N}=31)$ and Hairy Woodpeckers $(\mathrm{N}=23)$ focused on characteristics associated with dead or dying trees (bark retention and foliage retention) and fire effects. The models included interactions between beetle evidence and fire effects, and more complex additive effects of tree class, dbh, tree species, beetle evidence, bark retention and foliage retention (see Appendix 1).

The same candidate model set was considered separately for both control and thinned/burned sites. We tested the global model in each candidate model set for goodness of fit using the Hosmer and Lemeshow goodness of fit test [50]. A year effect was tested using the global model, and year was included in all models if the year increased the amount of variation explained while considering the addition of another parameter (i.e., decreased $\mathrm{AIC}_{c}$ ).

\section{Effect Size and Probability of Use}

To compare the effect size of explanatory variables in determining tree selection, we calculated the sum of the $\mathrm{AIC}_{c}$ weights $\left(\sum w_{i}\right)$ for all the models containing a variable [51, 54-57]. We averaged coefficient estimates from all models $<2 \Delta \mathrm{AIC}_{c}$ to interpret the influence of each explanatory variable on the probability of a tree being a used as a foraging site.

\section{RESULTS}

\section{Behavior}

Red-breasted Nuthatches spent the majority of observed foraging time gleaning from the surface of trees. Foraging bouts were spread across all vertical strata and tree components, with a majority of time spent foraging on live branches (Fig. 2). Mountain Chickadees spent the majority of observed foraging time gleaning from the surface of live branches in the highest stratum. In fact, Mountain Chickadees were rarely observed foraging on the boles of trees (Fig. 2). White-breasted Nuthatches spent the majority of observed foraging time gleaning from the surface of the tree boles in the middle stratum. Time not spent on the bole of the tree was evenly distributed between live and dead branches (Fig. 2). Black-backed Woodpeckers spent an overwhelming majority of observed foraging time pecking into the bark surface on the bole of the tree in the middle stratum, with remaining time evenly distributed between the low and high strata (Fig. 2). Hairy Woodpeckers spent a majority of observed foraging time pecking into the bark surface on the bole of the tree on all vertical strata, or on dead branches (Fig. 2).

\section{Encounter Rates}

Red-breasted Nuthatches and Mountain Chickadees were the only species commonly encountered in the control plots (Fig. 1). Based on encounter rates, Red-breasted Nuthatches were encountered significantly more often in control plots $(\mathrm{N}$ $\left.=249, \chi_{1}^{2}=5.82, P=0.020\right)$, while Mountain Chickadees were not encountered at different rates between control and treatment plots $\left(\mathrm{N}=99, \chi_{1}^{2}=0.81, P=0.37\right)$. Whitebreasted Nuthatches, Black-backed Woodpeckers and Hairy Woodpeckers were all encountered significantly more often in treatment plots $\left(\mathrm{N}=42, \chi^{2}{ }_{1}=9.29, P=0.00 ; \mathrm{N}=76, \chi^{2}{ }_{1}=\right.$ $\left.12.87, P=0.00 ; \mathrm{N}=92, \chi_{1}^{2}=6.17, P=0.01\right)$.

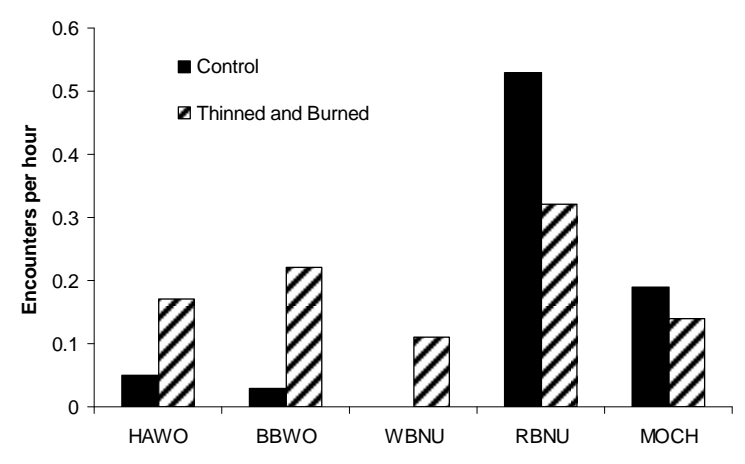

Fig. (1). Encounter rates of each species by treatment type. Encounter rates were calculated by dividing the number of foraging bouts recorded by the total number of hours of survey effort in each treatment type. RBNU = Red-Breasted Nuthatch, $\mathrm{MOCH}=$ Mountain Chickadee, WBNU = White-breasted Nuthatch, BBWO $=$ Black-backed Woodpecker, HAWO = Hairy Woodpecker.

\section{Microhabitat Selection}

The global model in each candidate model set adequately fit the data (Hosmer and Lemeshow goodness of fit $P>$ $0.05)$. Because we were not using logistic regression to predict individual trees that birds would forage on, but rather to determine general characteristics important in the selection of foraging substrates, we did not test the predictive power of the models. A correlation matrix was calculated among all variables in the global model. None of the variables in the top models were highly correlated $(r>0.75)$ and therefore all variables were kept in the analyses.

\section{Red-Breasted Nuthatches}

\section{Control Sites}

Overall, Red-breasted Nuthatches selected larger ponderosa pine trees as foraging substrates in control sites. The three models $<2 \Delta \mathrm{AIC}_{c}$ included tree diameter, tree species, tree class, canopy connections, and an interaction between tree species and tree diameter (Table 3). Tree diameter had the strongest influence on selection as indicated by $\sum w_{i}$ (Table 4). Tree species, in particular Douglas-fir, also 
had a strong negative influence (the 95\% confidence intervals for Douglas-fir did not overlap zero).

Table 3. The Best Approximating Model for Selection of Foraging Substrates in Control and Thinned/Burned Sites in Western Montana. Only Red-Breasted Nuthatches and Mountain Chickadees were Observed in Control Sites Enough to Estimate Selection

\begin{tabular}{|c|c|c|c|}
\hline Model $^{a}$ & $\Delta \mathrm{AIC}_{c}$ & $w_{i}$ & $\boldsymbol{K}$ \\
\hline \multicolumn{4}{|l|}{ Red-Breasted Nuthatch } \\
\hline \multicolumn{4}{|l|}{ Control } \\
\hline$d b h+s p p+d b h * s p p$ & 0 & 0.35 & 7 \\
\hline $\mathrm{dbh}+\mathrm{spp}+$ class + can & 0.44 & 0.28 & 6 \\
\hline $\mathrm{dbh}+\mathrm{spp}$ & 1.21 & 0.19 & 4 \\
\hline \multicolumn{4}{|l|}{ Thinned and Burned } \\
\hline $\mathrm{dbh}+\mathrm{can}$ & 0 & 0.35 & 3 \\
\hline $\mathrm{dbh}+$ class & 1.19 & 0.2 & 3 \\
\hline $\mathrm{dbh}+$ class + can $+\mathrm{spp}$ & 1.34 & 0.18 & 6 \\
\hline \multicolumn{4}{|l|}{ Mountain Chickadee } \\
\hline \multicolumn{4}{|l|}{ Control } \\
\hline $\mathrm{dbh}+$ class & 0 & 0.31 & 3 \\
\hline dbh & 1.04 & 0.18 & 2 \\
\hline $\mathrm{dbh}+$ class + class $* \mathrm{dbh}$ & 1.68 & 0.13 & 4 \\
\hline \multicolumn{4}{|l|}{$\begin{array}{l}\text { Thinned and Burned } \\
\qquad \mathrm{dbh}+\mathrm{can}\end{array}$} \\
\hline \multicolumn{4}{|l|}{ White-Breasted Nuthatch } \\
\hline \multicolumn{4}{|l|}{$\begin{array}{l}\text { Control } \\
\text { N/A }\end{array}$} \\
\hline \multicolumn{4}{|l|}{ Thinned and Burned } \\
\hline $\mathrm{dbh}$ & 0 & 0.38 & 2 \\
\hline $\mathrm{dbh}+$ class & 1.76 & 0.16 & 3 \\
\hline $\mathrm{dbh}+\mathrm{can}$ & 1.87 & 0.15 & 3 \\
\hline $\mathrm{dbh}+\mathrm{spp}$ & 1.95 & 0.14 & 4 \\
\hline \multicolumn{4}{|l|}{ Black-Backed Woodpecker } \\
\hline \multicolumn{4}{|l|}{$\begin{array}{l}\text { Control } \\
\text { N/A }\end{array}$} \\
\hline \multirow{3}{*}{$\begin{array}{l}\text { Thinned and Burned } \\
\qquad \begin{array}{l}\mathrm{dbh}+\mathrm{btl}+\mathrm{yr} \\
\text { class }+\mathrm{btl}+\mathrm{fir}+\mathrm{bt} 1 * \mathrm{fir}+\mathrm{yr}\end{array}\end{array}$} & & & \\
\hline & 0 & 0.48 & 4 \\
\hline & 1.73 & 0.2 & 10 \\
\hline \multicolumn{4}{|l|}{ Hairy Woodpecker } \\
\hline \multirow{2}{*}{\multicolumn{4}{|c|}{$\begin{array}{l}\text { Control } \\
\text { N/A }\end{array}$}} \\
\hline & & & \\
\hline \multicolumn{4}{|l|}{ Thinned and Burned } \\
\hline $\mathrm{dbh}+$ class & 0 & 0.45 & 3 \\
\hline $\mathrm{dbh}+$ class $+\mathrm{spp}+$ folC + fol $R$ & 1.21 & 0.24 & 10 \\
\hline
\end{tabular}

\section{Thinned and Burned Sites}

Overall, Red-breasted Nuthatches selected larger, live trees as foraging substrates in thinned and burned sites. The three models $<2 \Delta \mathrm{AIC}_{c}$ included combinations of tree diameter, tree species, tree class, and canopy connections (Table 3). Tree diameter had the strongest influence on selection as indicated by $\sum w_{i}$ (Table 4$)$. Both tree class and canopy connections had a strong influence based on $\sum w_{i}$. However, the number of canopy connections did not have a consistent influence on the selection of trees. Models showed both positive and negative influences, so when models were averaged, the coefficient estimates were essentially zero. Although tree species was included in the same number of candidate models, there was a much smaller influence based on $\sum w_{i}$ (Table 4 ).

\section{Mountain Chickadee}

\section{$\underline{\text { Control Sites }}$}

In general, Mountain Chickadees selected larger live trees as foraging substrates in the control sites. The three models $<2 \Delta \mathrm{AIC}_{c}$ contained tree diameter, tree class and an interaction between tree diameter and tree class (Table 3). Although tree class was in more candidate models than tree diameter, tree diameter had a much stronger influence on selection based on $\sum w_{i}$ (Table 4).

\section{Thinned and Burned Sites}

Mountain Chickadees selected larger trees with more canopy connections as foraging substrates in thinned and burned sites. Only one model was $<2 \Delta \mathrm{AIC}_{c}$ and contained tree diameter and canopy connections (Table 3 ), with both variables having substantial influence (Table 4).

\section{White-Breasted Nuthatch}

\section{Thinned and Burned Sites}

White-breasted Nuthatches selected larger trees as foraging substrates. The four models $<2 \Delta \mathrm{AIC}_{c}$ contained tree diameter, tree species, tree class, and canopy connections (Table 3). However, tree diameter was the only variable with a strong influence on selection and sufficiently small standard error to confidently interpret the effect on probability of use (Table 4).

\section{Black-Backed Woodpecker}

\section{Thinned and Burned Sites}

Overall, Black-backed Woodpeckers selected larger trees with beetle evidence present. The two models $<2 \Delta \mathrm{AIC}_{c}$ contained combinations of tree diameter, beetle evidence, tree class, fire effects, and the interaction between beetle evidence and fire effects (Table 3). Beetle evidence had the strongest influence on selection of a foraging substrate based on $\sum w_{i}$ (Table 4). In the top model, beetle evidence had a relatively small standard error $(\beta=2.16, \mathrm{SE}=0.39)$ and, therefore, we believe the presence of beetle evidence does have a strong positive effect on the probability of a Blackbacked Woodpecker foraging on a tree. However, when model averaged, the standard error for beetle evidence was large. This could be due to the second best model having a large number of variables and estimating the coefficients for all of these is difficult (Table 3). Tree diameter also had a substantial influence, however, the $\sum w_{i}$ of tree diameter is much smaller than beetle evidence despite being in more candidate models. Fire effects and tree class both had large standard errors and low contribution to the model. 
Table 4. Summary of the Effect of Variables on the Selection of Foraging Substrates for Each Species. The Sum of Weights $\left(\Sigma w_{i}\right)$ of All Models that Contain a Variable with the Number of Models in the Candidate Set that Include the Variable in Parentheses; Model-Averaged Coefficient Estimates and Standard Errors of Coefficient Estimates (SE) of Variables in the Top Logistic Regression Models

\begin{tabular}{|c|c|c|c|}
\hline Variables $^{a}$ & $\Sigma w_{i}$ & Coefficient & SE \\
\hline \multicolumn{4}{|l|}{ Red-Breasted Nuthatch } \\
\hline $\begin{array}{l}\text { Control } \\
\text { dbh } \\
\text { spp: Douglas fir } \\
\text { spp: other tree species } \\
\text { class } \\
\text { can }\end{array}$ & $\begin{array}{c}1.00(12) \\
0.87(12) \\
0.87(12) \\
0.35(14) \\
0.37(9) \\
\end{array}$ & $\begin{array}{c}0.07 \\
-1.26 \\
6.95 \\
-0.24 \\
0.12 \\
\end{array}$ & $\begin{array}{c}0.02 \\
1.01 \\
53.17 \\
0.55 \\
0.07 \\
\end{array}$ \\
\hline $\begin{array}{l}\text { Thinned and Burned } \\
\text { dbh } \\
\text { spp: Douglas fir } \\
\text { spp: other tree species } \\
\text { class } \\
\text { can }\end{array}$ & $\begin{array}{l}1.00(12) \\
0.22(12) \\
0.22(12) \\
0.51(14) \\
0.55(9)\end{array}$ & $\begin{array}{c}0.09 \\
0.15 \\
-0.33 \\
0.81 \\
-0.01\end{array}$ & $\begin{array}{l}0.01 \\
0.39 \\
0.85 \\
0.40 \\
0.10\end{array}$ \\
\hline \multicolumn{4}{|l|}{ Mountain Chickadee } \\
\hline $\begin{array}{l}\text { Control } \\
\text { dbh } \\
\text { class } \\
\text { dbh*class }\end{array}$ & $\begin{array}{c}1.00(12) \\
0.51(13) \\
0.17(4)\end{array}$ & $\begin{array}{c}0.08 \\
2.47 \\
-0.06\end{array}$ & $\begin{array}{l}0.04 \\
2.33 \\
0.10\end{array}$ \\
\hline $\begin{array}{l}\text { Thinned and Burned } \\
\text { dbh } \\
\text { can }\end{array}$ & $\begin{array}{c}1.00(12) \\
0.86(9)\end{array}$ & $\begin{array}{l}0.07 \\
0.12\end{array}$ & $\begin{array}{l}0.02 \\
0.11\end{array}$ \\
\hline \multicolumn{4}{|l|}{ White-Breasted Nuthatch } \\
\hline $\begin{array}{l}\text { Control } \\
\text { N/A }\end{array}$ & & & \\
\hline $\begin{array}{l}\text { Thinned and Burned } \\
\text { dbh } \\
\text { class } \\
\text { spp: Douglas fir } \\
\text { spp: other tree species } \\
\text { can }\end{array}$ & $\begin{array}{l}1.00(8) \\
0.32(8) \\
0.24(6) \\
0.24(6) \\
0.25(6)\end{array}$ & $\begin{array}{c}0.11 \\
-0.40 \\
-0.12 \\
1.34 \\
0.09\end{array}$ & $\begin{array}{l}0.02 \\
0.64 \\
0.70 \\
0.93 \\
0.16\end{array}$ \\
\hline \multicolumn{4}{|c|}{ Black-Backed Woodpecker } \\
\hline $\begin{array}{l}\text { Control } \\
\text { N/A }\end{array}$ & & & \\
\hline $\begin{array}{l}\text { Thinned and Burned } \\
\text { btl } \\
\text { dbh } \\
\text { class } \\
\text { fir1 } \\
\text { fir2 } \\
\text { fir3 } \\
\text { btl*fir1 } \\
\text { btl*fir2 } \\
\text { btl*fir3 }\end{array}$ & $\begin{array}{c}0.91(9) \\
0.57(11) \\
0.29(14) \\
0.33(9) \\
0.33(9) \\
0.33(9) \\
0.32(3) \\
0.32(3) \\
0.32(3)\end{array}$ & $\begin{array}{c}4.57 \\
0.03 \\
-1.02 \\
2.19 \\
2.36 \\
-0.30 \\
-9.33 \\
-9.15 \\
-7.21\end{array}$ & $\begin{array}{c}7.94 \\
0.01 \\
0.55 \\
1.10 \\
1.37 \\
1.53 \\
20.18 \\
20.20 \\
20.21\end{array}$ \\
\hline Hairy Woodpecker & & & \\
\hline $\begin{array}{l}\text { Control } \\
\text { N/A }\end{array}$ & & & \\
\hline $\begin{array}{l}\text { Thinned and Burned } \\
\text { dbh } \\
\text { class } \\
\text { spp: Douglas fir } \\
\text { spp: other tree species } \\
\text { fol1 } \\
\text { fol2 } \\
\text { fol3 } \\
\text { folR } \\
\text { folNA }\end{array}$ & $\begin{array}{c}0.96(7) \\
0.89(10) \\
0.33(7) \\
0.33(7) \\
0.31(8) \\
0.31(8) \\
0.31(8) \\
0.31(8) \\
0.31(8)\end{array}$ & $\begin{array}{c}0.10 \\
-1.98 \\
-1.87 \\
-0.37 \\
7.97 \\
7.93 \\
6.05 \\
-1.87 \\
5.27\end{array}$ & $\begin{array}{c}0.02 \\
0.91 \\
0.73 \\
1.33 \\
17.37 \\
17.38 \\
17.29 \\
1.98 \\
17.34\end{array}$ \\
\hline
\end{tabular}

\section{Hairy Woodpecker}

\section{Thinned and Burned Sites}

Overall, Hairy Woodpeckers selected larger, dead trees as a foraging substrate. The two models $<2 \Delta \mathrm{AIC}_{c}$ contained tree diameter, tree class, tree species, foliage color and foliage retention. Tree diameter and class had the strongest influence on foraging substrate selection. However, only tree diameter had a small enough standard error to be able to confidently interpret the effect on selection.

\section{DISCUSSION AND CONCLUSION}

Studies have shown silvicultural cutting alone can alter foraging patterns of bark-gleaning birds [58, 59] and concerns over how thinning and burning may affect these bird species - known to play important ecosystem roles have been expressed for more than a decade [49,60]. Our study showed that there were differences in foraging patterns during the breeding season both between treatment types and among species within each treatment type.

\section{Comparison Between Treatment Types}

Mountain Chickadees were the only species encountered at rates that were not statistically different on both treatment types. This is somewhat surprising because Mountain Chickadees are often associated with higher density forests [44]. As expected, we encountered Red-breasted Nuthatches significantly more often in the control sites compared to the thinned and burned sites [61]. In a similar study assessing the response in bird abundance to ponderosa pine forest restoration, Gaines et al. [44] detected a significantly higher abundance of both red-breasted nuthatches and mountain chickadees in untreated compared with treated sites.

White-breasted Nuthatches, Hairy Woodpeckers, and Blackbacked Woodpeckers were encountered almost exclusively in the thinned/burned sites. Gaines et al. [44] found a similar pattern for White-breasted Nuthatches. Hairy Woodpeckers are commonly found in a variety of habitat types, but are generally in higher densities in burned areas [62]. While we were not surprised to encounter Black-backed Woodpeckers more often in the thinned/burned sites compared to control sites, the degree of the difference was stronger than expected. In fact, Blackbacked Woodpeckers were encountered more often in the thinned/burned sites than any species besides Red-breasted Nuthatches (Fig. 1). Black-backed Woodpeckers are a wellknown fire specialist and are usually associated with mid to high severity post-burn habitat with a high density of snags [9, 22]. Although our thinned and burned sites were highly variable, we encountered Black-backed Woodpeckers at similar frequencies in all three treatment sites, all of which were characterized by a high proportion of live trees with a relatively open canopy.

Tree diameter, tree species, tree class, and the number of canopy connections were important in the selection of forage trees by Red-breasted Nuthatches in both treatment types. However, the effect size of these variables ranks differently, with tree species being more important in the control sites and tree class being more important in thinned and burned sites. This may not be an ecologically important difference, but an artifact of the characteristics of available trees in each treatment type. Red-breasted nuthatches selected against 
Douglas-fir trees in control sites where there was a high number of Douglas-fir trees available, while in thinned and burned sites, most Douglas-fir trees were removed as part of the treatment. Similarly, the selection of live trees may be detectable only in the thinned and burned sites because not many dead trees are available in control sites.

\section{Comparison Among Species}

Within guilds, sympatric birds within sites often exploit different resources [33, 42, 63-65]. On our sites, the five species exploited different sections of trees for resources. The smaller birds primarily gleaned insects from the bark surface and the woodpeckers primarily pecked into the bark to find insects (e.g. beetle larvae; Fig. 2). Within these two main groups, the birds seemed to exploit different portions of
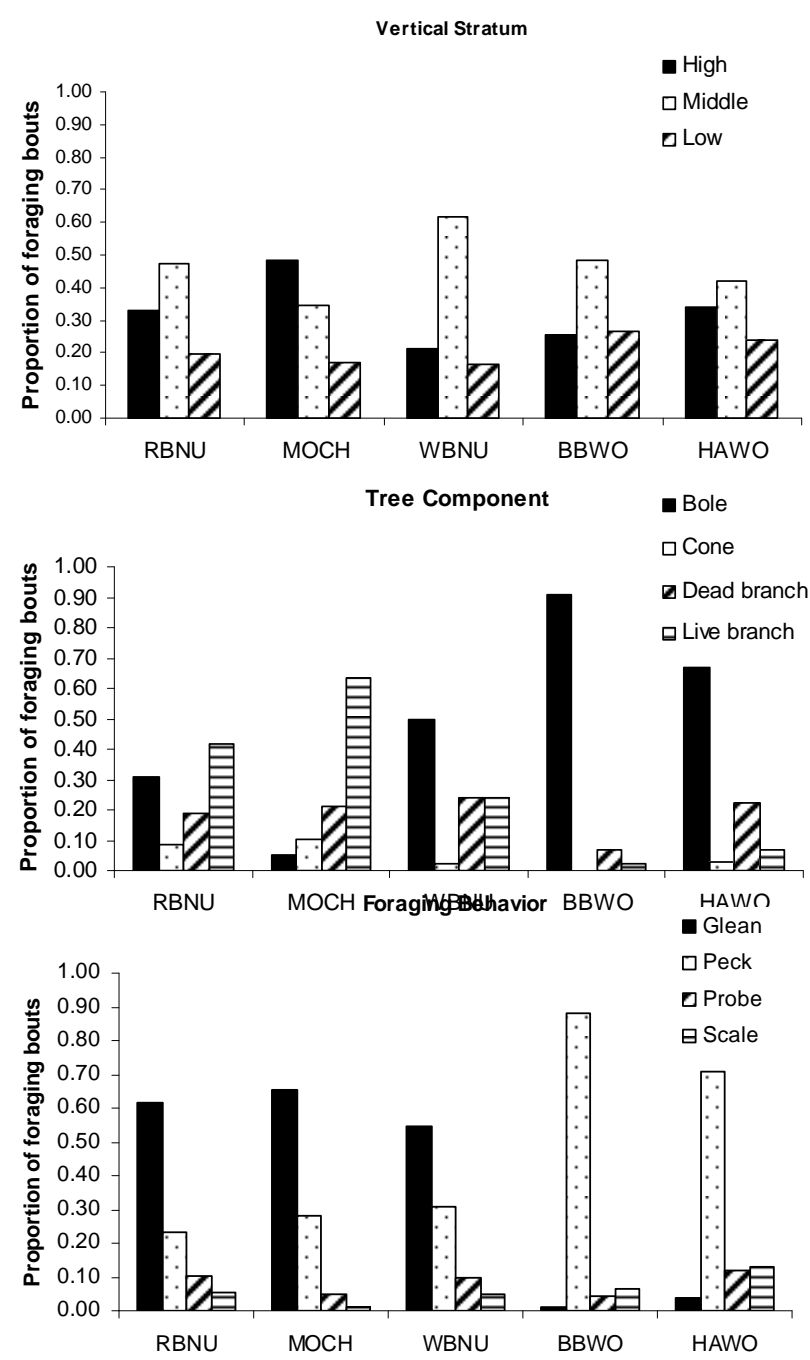

Fig. (2). Summary of foraging behaviors by each bird species. Top: the proportion of foraging bouts recorded on the vertical stratum of the tree; Middle: the proportion of foraging bouts recorded on various tree components; Bottom: proportion of foraging bouts recorded where the bird displayed a particular foraging behavior. RBNU $=$ Red-Breasted Nuthatch, $\mathrm{MOCH}=$ Mountain Chickadee, WBNU $=$ White-breasted Nuthatch, BBWO = Black-backed Woodpecker, HAWO = Hairy Woodpecker. the trees. Among the gleaners, Mountain Chickadees spent a majority of their time foraging on live branches, Whitebreasted Nuthatches foraged mainly on the bole of trees and Red-breasted Nuthatches exploited the entire tree fairly evenly. Black-backed Woodpeckers foraged almost exclusively on the tree bole, while Hairy Woodpeckers exploited other tree sections, especially dead branches.

All species selected larger trees for foraging. For example, in thinned/burned sites the probability of a Redbreasted Nuthatch foraging on a tree increases from 0.19 when the tree is $12.7 \mathrm{~cm}$ diameter to 0.71 for a $38.1 \mathrm{~cm}$ diameter tree, all other things equal. In comparison, the probability of a Black-backed Woodpecker foraging on a increases from 0.18 when the tree is $12.7 \mathrm{~cm}$ diameter to 0.33 for a $38.1 \mathrm{~cm}$ diameter tree, all other things equal. The selection of larger trees is consistent with foraging patterns of nuthatches and woodpeckers in other habitat types [21, 64-67]. Both gleaners and excavating species likely select larger trees due to an increase in available prey in larger trees.

Fuel reduction treatments of this type typically reduce the available small diameter trees, while leaving larger diameter target species (i.e., ponderosa pine, western larch). Therefore, selection of larger diameter trees as foraging substrates overlaps well with treatment objectives. Although tree diameter was often the only variable that we could confidently conclude influenced forage tree selection, other variables likely influence selection. Small sample sizes combined with large variation in the data caused several variables to have large standard errors. Each species had specific variables that should still be considered as being potentially important because they explained enough variation to be included in the best approximating model set (Table 4). In particular tree class (e.g. live versus dead) was in the top model for all five species.

Beetle evidence is the driving factor in predicting the probability of a Black-backed Woodpecker selecting a tree for a foraging bout (Fig. 3, Table 4). This is consistent with the observed behavior on our sites of pecking on the bole of the tree. Black-backed Woodpeckers select snags that contain high densities of wood-boring insects [30] and wood-boring beetle presence has been suggested as a primary indicator of black-backed woodpecker density [68]. These studies, combined with our findings, indicate that bark and wood-boring beetle presence following prescribed fire is important for providing good foraging habitat for Blackbacked Woodpeckers.

Bark beetles respond to disturbance and often persist at high levels for the first few years post-disturbance. We observed this trend on our sites, with high levels of beetle attacks occurring throughout the 2002 season. The most common beetle evidence was produced by red turpentine beetles (Dendroctonus valens Lec.) and wood-boring beetles (Buprestidae and Cerambycidae). Red turpentine beetles inhabit trees injured by fire, logging operations, or other damage [69]. Buprestids and cerambycids both attack recently cut trees or those killed by bark beetles [69]. Therefore, the presence of these beetle species does not increase tree mortality and should not conflict with other forest management objectives. 


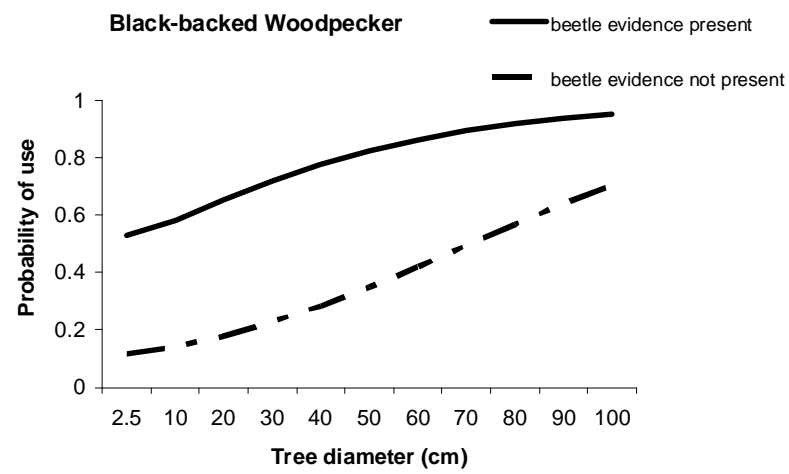

Fig. (3). The probability of a black-backed woodpecker foraging on a tree with beetle evidence and a tree without beetle evidence across a range of tree diameters.

Hairy Woodpeckers exhibited a more complex pattern of selection. Consistent with previous research [28, 67] our data indicate that Hairy Woodpeckers forage selectively on recently dead trees, which is reflected in the inclusion of foliage color and retention in the set of best models. While we were not able to estimate these foliage parameters precisely, we believe they need to be a component in evaluation of post-fire habitat use. Post-fire habitat differs dramatically depending on the time since fire. Trees that have been recently killed, as indicated by retention of yellow or red needles, present a different suite of food resources than older snags. Researchers and managers alike should consider the time since disturbance in post-fire landscapes when evaluating the habitat potential for different species.

\section{Management Implications}

We found that species usually encountered after wildfires, including Black-backed Woodpeckers, Hairy Woodpeckers and White-breasted Nuthatches [8, 9, 29, 33, 70], were encountered primarily in our thinned/burned sites. Furthermore, the fact that all five species were commonly encountered in the thinned/burned sites indicates that the fuel reduction/forest restoration treatment employed here provides foraging habitat for this guild. Fuel reduction/habitat restoration treatments in pine/fir forests typically reduce small diameter Douglas-fir trees, while leaving larger diameter target species (i.e., ponderosa pine, western larch). Thus, the characteristics of trees retained in these treatments overlap with those selected as foraging substrates by all species observed.

Overall these trends suggest that fuel reduction/restoration treatments in ponderosa pine will not negatively affect the food resources of the bark-foraging community present before treatment. Indeed, based on our encounter rates in non-treated sites, the treatment appears to increase the availability of foraging substrates for Whitebreasted Nuthatches, Black-backed and Hairy Woodpeckers. Thus, it may be possible to use fuel management techniques to create woodpecker foraging habitat.

However, we must be cautious in interpreting our results because habitat quality is best measured by estimating population vital rates (e.g., reproductive success and survival). There is a lack of information on vital rates in thinned and prescribed burned areas; this information is necessary to assess the quality of this rapidly increasing habitat type. We observed both species nesting in treated sites both years, but did not quantify nest success. As land management agencies continue to increase the use of prescribed fire to meet ecological restoration and public safety objectives, it is imperative that forest and wildlife managers better understand the potential impacts on fireassociated species.

\section{ACKNOWLEDGEMENTS}

This is Contribution Number 215 of the National Fire and Fire Surrogate Project (FFS), funded by the U.S. Joint Fire Science Program. Diana Six volunteered time and expertise in the field of bark beetle identification and ecology. Mick Harrington designed fire severity characterization protocols. Hank Goetz and Frank Maus provided logistical support at Lubrecht Experimental Forest. Bob Rich, with the Montana Department of Natural Resources (DNRC), provided logistical support with DNRC field sites. This research would not have been possible without the endless hard work of field assistants: Cory Engjker, Kevin Fairhurst, Jamie Garten, Jessica Harris, Tamra Hatch, Elizabeth Joyce, Alex Kavicky, Allison Landro, Cory Michell, Erin O’Brien, Natasha Osborn, and Luke Stevens. We thank Carl Fiedler for providing useful comments on this manuscript.

\section{APPENDIX}

\section{Table A1. Candidate Model Set for Red-Breasted Nuthatches}

\begin{tabular}{|l|}
\hline Logit \\
\hline \hline NULL \\
\hline class \\
\hline dbh \\
\hline Douglas fir + other species \\
\hline fir $1+$ fir $2+$ fir 3 \\
\hline btl \\
\hline can \\
\hline class + dbh \\
\hline class + Douglas fir + other species \\
\hline class + btl \\
\hline class + fir $1+$ fir $2+$ fir 3 \\
\hline class + can \\
\hline dbh + Douglas fir + other species \\
\hline dbh + btl \\
\hline dbh + fir $1+$ fir + fir 3 \\
\hline dbh + can \\
\hline Douglas fir + other species + btl \\
\hline Douglas fir + other species + fir $1+$ fir $2+$ fir 3 \\
\hline Douglas fir + other species + can \\
\hline btl + fir ++ fir + fir 3 \\
\hline btl + can \\
\hline fir $1+$ fir2 + fir3 + can \\
\hline
\end{tabular}


(Table A1) contd.....

\section{Logit}

class $+\mathrm{btl}+\mathrm{btl}{ }^{*}$ class

class $+\mathrm{dbh}+$ class $* \mathrm{dbh}$

class + Douglas fir + other species + class*Douglas fir +class*other species

Douglas fir + other species + btl + Douglas fir*btl + other species*btl

$\mathrm{dbh}+$ Douglas fir + other species $+\mathrm{dbh} *$ Douglas fir $+\mathrm{dbh} *$ other species

btl + fir $1+$ fir $2+$ fir $3+$ fir $1 * b t l+$ fir $2 * b t l+$ fir $3 * b t l$

class + Douglas fir + other species + can

class $+\mathrm{dbh}+$ Douglas fir + other species + class*Douglas fir +

class* other species

class $+\mathrm{dbh}+$ Douglas fir + other species + class $*$ dbh

class $+\mathrm{dbh}+$ Douglas fir + other species + can

class $+\mathrm{dbh}+$ Douglas fir + other species + can + class $*$ Douglas

fir + class*other species + class $*$ dbh

\section{Global model:}

class $+\mathrm{dbh}+$ Douglas fir + other species + fir $1+$ fir $2+$ fir $3+$ btl + can + btl*class +

class*dbh + class*Douglas fir + class*other species + Douglas fir*btl + other

species*btl $+\mathrm{dbh} *$ Douglas fir $+\mathrm{dbh} *$ other species + fir $1 * b t l+$ fir $2 * b t l+$ fir3*btl

Table A2. Candidate Model Set for Mountain Chickadee

\begin{tabular}{|l|}
\hline Logit \\
\hline \hline NULL \\
\hline Class \\
\hline dbh \\
\hline Douglas fir + other species \\
\hline fir $1+$ fir $2+$ fir 3 \\
\hline Can \\
\hline class + dbh \\
\hline class + Douglas fir + other species \\
\hline class + fir $1+$ fir $2+$ fir3 \\
\hline class + can \\
\hline dbh + Douglas fir + other species \\
\hline dbh + fir $1+$ fir $2+$ fir 3 \\
\hline dbh + can \\
\hline Douglas fir + other species + fir $1+$ fir $2+$ fir 3 \\
\hline Douglas fir + other species + can \\
\hline fir $1+$ fir2 + fir3 + can \\
\hline class + dbh + class*dbh \\
\hline class + Douglas fir + other species + class $*$ Douglas fir + class*other \\
\hline
\end{tabular}

(Table A2) contd...

\section{Logit}

$\mathrm{dbh}+$ Douglas fir + other species $+\mathrm{dbh}$ *Douglas fir $+\mathrm{dbh} *$ other species

class + Douglas fir + other species + can

class $+\mathrm{dbh}+$ Douglas fir + other species + class*Douglas fir +

class*other species

class $+\mathrm{dbh}+$ Douglas fir + other species + class $* d b h$

class $+\mathrm{dbh}+$ Douglas fir + other species + can

class $+\mathrm{dbh}+$ Douglas fir + other species + can + class*Douglas

fir + class* other species + class $*$ dbh

\section{Global model:}

class $+\mathrm{dbh}+$ Douglas fir + other species + fir $1+$ fir $2+$ fir $3+$ can +

class*Douglas fir + class $*$ other species + class $* d b h+d b{ }^{*}$ Douglas fir +

dbh*other

Table A3. Candidate Model Set for White-Breasted Nuthatch

\begin{tabular}{|l|}
\hline Logit \\
\hline \hline NULL \\
\hline class \\
\hline dbh \\
\hline Douglas fir + other species \\
\hline fir1 + fir2 + fir3 \\
\hline can \\
\hline btl \\
\hline class + dbh \\
\hline class + Douglas fir + other species \\
\hline class + can \\
\hline dbh + Douglas fir + other species \\
\hline dbh + can \\
\hline fir1 + fir $2+$ fir3 + btl \\
\hline class + dbh + Douglas fir + other species \\
\hline class + dbh + can \\
\hline class + Douglas fir + other species + can \\
\hline Global Model: \\
\hline
\end{tabular}

Table A4. Candidate Model set for Black-backed Woodpeckers

\section{Logit}

NULL

class + year

$\mathrm{dbh}+$ year

Douglas fir + other species + year

can + year 
(Table A4) contd.....

\section{Logit}

fir $1+$ fir $2+$ fir $3+$ year

bark $1+$ bark $2+$ bark $3+$ year

btl + year

folR + folNA + fol $1+$ fol $2+$ fol $3+$ year

class $+\mathrm{dbh}+$ year

class + Douglas fir + other species + year

class + btl + year

class + fir $1+$ fir $2+$ fir $3+$ year

class + can

class + folR + folNA + foll + fol $2+$ fol $3+$ year

class + bark $1+$ bark $2+$ bark $3+$ year

$\mathrm{dbh}+$ Douglas fir + other species + year

$\mathrm{dbh}+\mathrm{btl}+$ year

$\mathrm{dbh}+$ fir $1+$ fir $2+$ fir $3+$ year

$\mathrm{dbh}+$ folR + folNA + fol $1+$ fol $2+$ fol $3+$ year

$\mathrm{dbh}+$ bark $1+$ bark $2+$ bark $3+$ year

btl + fir $1+$ fir $2+$ fir $3+$ year

$b t 1+$ fir $1+$ fir $2+$ fir $3+$ fir $1 * b t l+$ fir $2 * b t l+$ fir $3 * b t l+$ year

class $+\mathrm{dbh}+$ class $* \mathrm{dbh}+$ year

class + Douglas fir + other species + class*Douglas fir + class*other

species + year

class + fir $1+$ fir $2+$ fir $3+$ btl + fir $1 * b t l+$ fir $2 * b t l+$ fir $3 * b t l+$

year

class + fir $1+$ fir $2+$ fir $3+$ btl + folR + folNA + fol $1+$ fol $2+$ fol $3+$

bark $1+$ bark $2+$ bark $3+$ year

class $+\mathrm{dbh}+$ Douglas fir + other species + folR + folNA + foll

+ fol $2+$ fol $3+$ year

$\mathrm{btl}+$ fir $1+$ fir $2+$ fir $3+$ folR + folNA + fol $1+$ fol $2+$ fol $3+$

year

$\mathrm{dbh}+$ folR + folNA + foll + fol $2+$ fol $3+$ Douglas fir + other

species + year

\section{Global Model:}

class + dbh + Douglas fir + other fir $1+$ fir $2+$ fir $3+$ bark $1+$ bark $2+$

bark $3+$ btl folR + folNA + fol $1+$ fol $2+$ fol $3+$ fir $1 * b t l+$ fir $2 * b t l$

+ fir $3 * b t l+$ class $* d b h+$ class $*$ Douglas fir + class $*$ other species + year

Table A5. Candidate Model Set for Hairy Woodpeckers

\begin{tabular}{|l|}
\hline Logit \\
\hline \hline NULL \\
\hline class \\
\hline dbh \\
\hline Douglas fir + other species \\
\hline can \\
\hline
\end{tabular}

(Table A5) contd.....

\begin{tabular}{|c|}
\hline Logit \\
\hline fir $1+$ fir $2+$ fir 3 \\
\hline bark $1+$ bark $2+$ bark 3 \\
\hline btl \\
\hline folR + folNA + fol $1+$ fol $2+$ fol 3 \\
\hline class $+\mathrm{dbh}$ \\
\hline class + Douglas fir + other species \\
\hline class + folR + folNA + fol $1+$ fol $2+$ fol 3 \\
\hline $\mathrm{dbh}+$ Douglas fir + other species \\
\hline $\mathrm{dbh}+$ folR + folNA + foll + fol $2+$ fol 3 \\
\hline Douglas fir + other species + folR + folNA + foll + fol $2+$ fol 3 \\
\hline btl + fir $1+$ fir $2+$ fir 3 \\
\hline $\mathrm{btl}+$ fir $1+$ fir $2+$ fir $3+$ fir $1 * b t l+$ fir $2 * b t l+$ fir $3 * b t l$ \\
\hline class $+\mathrm{dbh}+$ class $* \mathrm{dbh}$ \\
\hline $\begin{array}{l}\text { class }+ \text { Douglas fir }+ \text { other species }+ \text { class* Douglas fir }+ \text { class* other } \\
\text { species }\end{array}$ \\
\hline $\begin{array}{l}\text { class }+ \text { folR }+ \text { folNA }+ \text { fol } 1+\text { fol } 2+\text { fol } 3+\text { folR } * \text { fol } 1+\text { folR } * \text { fol } 2+ \\
\text { folR } * \text { fol } 3+\text { folNA } * \text { fol } 1+\text { folNA } * \text { fol } 2+\text { folNA } * \text { fol } 3\end{array}$ \\
\hline $\begin{array}{l}\text { btl }+ \text { fir } 1+\text { fir } 2+\text { fir } 3+\text { folR }+ \text { folNA }+ \text { fol } 1+\text { fol } 2+\text { fol } 3+\text { bark } 1+ \\
\text { bark } 2+\text { bark } 3\end{array}$ \\
\hline $\begin{array}{l}\text { class }+ \text { dbh }+ \text { folR }+ \text { folNA }+ \text { fol } 1+\text { fol } 2+\text { fol } 3+\text { Douglas fir }+ \text { other } \\
\text { species }\end{array}$ \\
\hline $\begin{array}{l}\text { Global Model: } \\
\text { class }+ \text { dbh }+ \text { Douglas fir }+ \text { other species }+ \text { can }+ \text { fir } 1+\text { fir } 2+\text { fir } 3+ \\
\text { bark } 1+\text { bark } 2+\text { bark } 3+\text { btl }+ \text { folR }+ \text { folNA }+ \text { fol } 1+\text { fol } 2+\text { fol } 3+ \\
\text { fir } 1 * \text { btl }+ \text { fir } 2 * \text { btl }+ \text { fir } 3 * \text { btl }+ \text { class } * \text { Douglas fir }+ \text { class } * \text { other species }+ \\
\text { folR } * \text { fol } 1+\text { folR* fol } 2+\text { folR } * \text { fol } 3+\text { folNA } * \text { fol } 1+\text { folNA } * \text { fol } 2+ \\
\text { folNA } * \text { fol } 3\end{array}$ \\
\hline
\end{tabular}

\section{REFERENCES}

[1] Arno SF, Harrington MF, Fiedler CE, and Carlson CE. Restoring fire- dependent ponderosa pine forest in western Montana. Restor Manag Notes 1995; 13: 32-36.

[2] Fiedler CE. Silvicultural treatments. Pages 19-20 in H. Y. Smith, editor. The Bitterroot Ecosystem Management Research Project: What we have learned - symposium proceedings. U.S. Department of Agriculture, Forest Service, Missoula, 2000.

[3] Harrod RJ, McRae BH, Hartl WE. Historical stand reconstruction in ponderosa pine forests to guide silvicultural prescriptions. Forest Ecol Manag 1999; 114: 433-446.

[4] Covington WW, Fule PZ, Moore MM, et al. Restoring ecosystem health in ponderosa pine forests of the southwest. J Forest 1997; 95: 23-29.

[5] Harris GR, Covington WW. The effect of a prescribed fire on nutrient concentration and standing crop of understory vegetation in ponderosa pine. Can J Forest Res 1983; 13: 501-507.

[6] Smith JK. Wildland fire in ecosystems: effects of fire on fauna. Page 83. U.S. Department of Agriculture, Rocky Mountain Research Station, Ogden, UT., 2000.

[7] Tiedemann AR, Klemmedson JO, Bull EL. Solution of forest health problems with prescribed fire: are forest productivity and wildlife at risk? Forest Ecol Manag 2000; 127: 1-18.

[8] Hutto RL. Composition of bird communities following standreplacement fires in Northern Rocky Mountain (U.S.A.) conifer forests. Conserv Biol 1995; 9: 1041-1058.

[9] Dixon R, Saab V. Black-backed woodpecker. Birds North Am 2000; 509:1-20. 
[10] Saab V, Powell HDW. Fire and avian ecology in North America: process influencing system. Stud Avian Biol 2005; 30: 1-13.

[11] Martin K, Aitken KEH, Wiebe KL. Nest sites and nest webs for cavity- nesting communities in Interior British Columbia, Canada: nest characteristics and niche partitioning. Condor 2004; 106: 5-19.

[12] Mikusiński G. Woodpeckers: distribution, conservation, and research in a global perspective. Ann Zool Fenn 2006; 43: 86-95.

[13] Fayt P, Machmer MM, Steeger C. Regulation of spruce bark beetles by woodpeckers: a literature review. Forest Ecol Manag 2005; 206: 1-14.

[14] Farris KL, Huss MJ, Zack S. The role of foraging woodpeckers in the decomposition of ponderosa pine snags. Condor 2004; 106: 5059.

[15] Jackson JA, Jackson BJS. Ecological relationships between fungi and woodpecker cavity sites. Condor 2004; 106: 37-49.

[16] USDA Forest Service. Snag protocol for Region One, 2000.

[17] Hutto RL. Toward meaningful snag-management guidelines for postfire salvage logging in North American conifer forests. Conserv Biol 2006; 20: 984-993.

[18] Thomas JW. Wildlife habitats in managed forests: the Blue Mountains of Oregon and Washington. USDA Forest Service, 1979.

[19] Li P, Martin TE. Nest-site selection and nesting success of cavity nesting birds in high elevation forest drainages. Auk 1991; 108: 405-418.

[20] Saab V, Dudley J. Responses of cavity-nesting birds to standreplacement fire and salvage logging in ponderosa pine/Douglas fir. Rocky Mountain Research Station: USDA Forest Service. Report nr RMRS-RP-11. 17 p., 1998.

[21] Weikel JM, Hayes JP. The foraging ecology of cavity nesting birds in young forests of the northern coast range of Oregon. Condor 1999; 101: 58-66.

[22] Saab V, Brannon R, Dudley J, Donohoo L, Vanderzanden D, Johnson V, Lachowski H.. Selection of fire-created snags at two spatial scales by cavity-nesting birds. USDA Forest Service Report PSW-GTR-181 14 p., 2002.

[23] Steeger C, Hitchcock C. Influence of forest structure and diseases on nest- site selection by red-breasted nuthatches. J Wildl Manag 1998; 62: 1349-1358.

[24] McEllin SM. Nest sites and population demographies of whitebreasted and pygmy nuthatches in Colorado. Condor 1979; 81: 348-352.

[25] Caton EL. Effects of fire and salvage logging on the cavity nesting bird community in Northwestern Montana. University of Montana, Missoula, 1996.

[26] Powell HDW. The influence of prey density on post-fire habitat use of the black-backed woodpecker. University of Montana, Missoula, 2000.

[27] Brawn JD, Balda RP. Population biology of cavity nesters in northern Arizona: do nest sites limit breeding densities. Condor 1988; 90: 61-71.

[28] Conner RN, Jones SD, Jones GD. Snag condition and woodpecker foraging ecology in a bottomland hardwood forest. Wilson Bull 1994; 106: 242-257.

[29] Kreisel KJ, Stein SJ. Bird use of burned and unburned coniferous forests during winter. Wilson Bull 1999; 111: 243-250.

[30] Nappi A, Drapeau P, Giroux JF, Savard JP. Snag use by foraging black- backed woodpeckers (Picoides arcticus) in a recently burned eastern boreal forest. Auk 2003; 120: 505-511.

[31] Otvos IS. Studies on avian predators of Dendroctonus brevicomis LeConte (Coleoptera: Scolytidae) with special reference to Picidae. Can Entomol 1965; 97: 1184-1199.

[32] Otvos IS, Stark RW. Arthropod food of some forest-inhabiting birds. Can Entomol 1985; 117: 971-990.

[33] Murphy EC, Lehnhausen WA. Density and foraging ecology of woodpeckers following a stand-replacement fire. J Wildl Manag 1998; 62: 1359-1372.

[34] Arno SF, Harrington MF, Fiedler CE, Carlson CE. Using silvicultural and prescribed fire to reduce fire hazard and improve health in ponderosa pine forests. Pages 114-118. Forest Vegetation Management Conference. USDA, Forest Service 1996.

[35] Smith HY, Arno SF. Eighty-eight years of change in a managed ponderosa pine forest. Page 55. USDA Rocky Mountain Research Station, 1999.
[36] Veblen TT, Kitzberger T, Donnegan J. Climatic and human influences on fire regimes in ponderosa pine forests in the Colorado Front Range. Ecol Appl 2000; 10: 1178-1195.

[37] USDA. Forest Service. "Hazardous fuels reduction" National Fire Plan. January 28, 2002. http://www.hazfuels_1_28_02.cfm (January 31,2003 ).

[38] White House. Healthy forests: an initiative for wildfire prevention and stronger communities. 2002 (www.whitehouse.gov/infocus/ healthyforests/Healthy_Forests_v2.pdf) accessed November 2006.

[39] Harris MA. Habitat use among woodpeckers in forest burns. University of Montana, Missoula, 1982.

[40] Bate LJ. Monitoring woodpecker abundance and habitat in the central Oregon Cascades. University of Idaho, Moscow 1995.

[41] Hagar JC, McComb WC, Emmingham WH. Bird communities in commercially thinned and unthinned Douglas-fir stands of western Oregon. Wildlife Society Bulletin 1996; 24:353-366.

[42] Bull EL, Peterson SR, Thomas JW. Resource partitioning among woodpeckers in Northeastern Oregon. Pacific Northwest Research Station, Forest Service 1986.

[43] Haggard M, Gaines WL. Effects of stand-replacement fire and salvage logging on a cavity-nesting bird community in Eastern Cascades, Washington. Northwest Sci 2001; 75: 387-396.

[44] Gaines WL, Haggard M, Lehmkuhl JF, Lyons AL, Harrod RJ. Short-term response of land birds to ponderosa pine restoration. Restor Ecol 2007; 15: 670-678.

[45] Grubb, Jr., TC and VV Pravosudov. White-breasted Nuthatch (Sitta carolinensis), The Birds of North America Online (A. Poole, Ed.) Ithaca: Cornell Lab of Ornithology; 2008; Retrieved from the Birds of North America Online: http://bna.birds.cornell.edu/bna/species/ 054doi:10.2173/bna.54

[46] Ryan KC, Noste NV. Evaluating prescribed fires. In Proceedings of the symposium and workshop on wilderness fire (Lotan, J. E., B. Kilgore, M. Fischer, C. William, and W. Robert eds.) USDA Forest Service General Technical Report INT-182, pp. 230-238, 1985.

[47] Hejl S, Verner J, Bell GW. Sequential versus initial observations in studies of avian foraging. Stud Avian Biol 1990; 13: 166-173.

[48] Bell GW, Hejl S, Verner J. Proportional use of substrates by foraging birds: model considerations on first sightings and subsequent observations. Stud Avian Biol 1990; 13: 161-165.

[49] Morrison ML, With KA, Timossi IC, Block WM, Milne K. Foraging behavior of bark-foraging birds in the Sierra Nevada. Condor 1987; 89: 201-204.

[50] Hosmer DW, Lemeshow S. Applied logistic regression. John Wiley and Sons, Inc., New York, 2000.

[51] Burnham KP, Anderson DR. Model selection and multimodel inference: a practical information-theoretic approach. SpringerVerlag, New York, 2002.

[52] Ghalambor CK, Martin TE.1999. Red-breasted Nuthatch (Sitta canadensis) In The Birds of North America, No. 459 (A. Poole, Ed.) The Birds of North America, Inc. Philadelphia, 1999.

[53] McCallum DA, Grundel R, Dahlsten DL. Mountain Chickadee (Poecile gambeli). In The Birds of North America, No. 453 (A. Poole and F. Gill, Eds.). The Birds of North America, Inc. Philadelphia, 1999.

[54] Palmer GG, Fitzsimmons JA, Antos MJ, White JG. Determinants of native avian richness in suburban remnant vegetation: implications for conservation planning. Biol Conserv 2008; 141: 2329-2341.

[55] Rose AP. 2009. Temporal and individual variation in offspring provisioning by tree swallows: a new method of automated nest attendance monitoring. PLoSOne 2009; 4:e4111.

[56] Martin KJ, Lutz RS, Worland M. Golden-winged warbler habitat use and abundance in northern Wisconsin. Wilson J Ornithol 2007; 119: 523-532.

[57] Moynahan BJ, Lindberg MS, Rotella JJ, Thomas JW. Factors affecting nest survival of greater sage-grouse in northcentral Montana. J Wildl Manag 2007; 71: 1773-1783.

[58] Szaro RC, Balda RP. Effects of harvesting ponderosa pine on nongame bird populations. Pages 1-8. Rocky Mountain Forest and Range Experiment Station, Forest Service, U. S. Department of Agriculture, 1979

[59] Weikel JM. Habitat use by cavity nesting birds in young thinned and unthinned Douglas-fir forests in western Oregon, Oregon State University, USA 1997. 
[60] Brennan LA, Morrison ML, Dahlsten DL. Comparative foraging dynamics of chestnut-backed and mountain chickadees in the western Sierra Nevada. Northwestern Nat 2000; 81: 129-147.

[61] Adams EM, Morrison ML. Effects of forest stand structure and composition on red-breasted nuthatches and brown creepers. J Wildl Manag 1993; 57: 616-629.

[62] Smucker KM, Hutto RL, Steele BM. Changes in bird abundance after wildfire: importance of fire severity and time since fire. Ecol Appl 2005; 15: 1535-1549.

[63] Morrison ML, With KA. Interseasonal and intersexual resource partitioning in hairy and white-headed woodpeckers. Auk 1987; 104: $225-233$

[64] Lundquist RW, Manuwal DA. Seasonal differences in foraging habitat of cavity nesting birds in the southern Washington Cascades. Stud Avian Biol 1990; 13: 218-225.
[65] Villard P, Beninger CW. Foraging behavior of male black-backed and hairy woodpeckers in a forest burn. J Field Ornithol 1993; 64: 71-76.

[66] Villard P. Foraging behavior of black-backed and three-toed woodpeckers during spring and summer in a Canadian boreal forest. Can J Zool 1994; 72: 1957-1959.

[67] Gunn JS, and Hagan JI. Woodpecker abundance and tree use in uneven-aged management, and unmanaged, forest in northern Maine. Forest Ecol Manag 2000; 126:1-12.

[68] Powell HD, Hejl S, Six D. Measuring woodpecker food: a simple method for comparing wood-boring beetle abundance among firekilled trees. J Field Ornithol 2002; 73: 130-140.

[69] Hagle SK. A field guide to diseases and insect pests of Idaho and Montana Forests. USDA Forest Service, Northern Region, 1987.

[70] Hoffman NJ. Distribution of Picoides woodpeckers in relation to habitat disturbance within the Yellowstone area. Montana State University, Bozeman, 1997.

(C) Pierson et al.; Licensee Bentham Open.

This is an open access article licensed under the terms of the Creative Commons Attribution Non-Commercial License (http://creativecommons.org/licenses/by$\mathrm{nc} / 3.0 /$ ) which permits unrestricted, non-commercial use, distribution and reproduction in any medium, provided the work is properly cited. 